\title{
СОЦАЛЬНО-ПСИХОЛОГІЧНИЙ ПРОЦЕС СТАНОВЛЕННЯ ОБДАРОВАНОЇ ОСОБИСТОСТІ В УМОВАХ ТРАНСФОРМАЦІЙНИХ ЗМІН СОЦІУМУ
}

У статті запропоновано комплексний підхід до дослідження розвитку обдарованої особистості в умовах освітнього середовища вузу; визначені наукові передумови та практичні обтрунтування розробки соціально-психологічної моделі освітнього середовища вузу, спрямованої на розвиток обдарованої особистості, щз включає в себе суб'єктне поле, змістовне поле, організаційне поле, інтегроване з ними поле взаємодії з соиіумом. Виокремлено рівні прояву творчого розвитку особистості: низький рівень (не вірить у власні можливості, не бажає брати участь в різноманітних видах навчальної та позанавчальної творчої діяльності, інертний до участі в роботі творчих об'єднань); середній рівень (сумнівається у свойх можливостях, потребує додаткових стимулів при ініціюванні творчої активності, не наважується брати творчу ініціативу на себе); високий рівень (бере активну участь в різноманітних видах навчальної та позанавчальної творчої діяльності; є ініціатором, здатний на створення широкого спектра самостійних задумів, знаходить нестандартні иляхи і втілює їх у самостійні проекти). Розроблено механізм реалізації моделі освітнього середовища вузу щзодо поетапного підвищення рівня прояву творчого розвитку особистості. Постановка і вирішення проблеми пошуку можливостей освітнього середовища вузу для розвитку обдарованої особистості сприяє реалізації ідей особистісно орієнтованої психології; сконструйована модель освітнього середовища вузу, спрямована на розвиток обдарованої особистості, $i$ адекватний механізм ї̈ реалізації в освітньому проиесі вузу відповідає положенням нової парадигми освіти, вносить певний внесок у теорію розвитку особистості.

Ключові слова: особистість, обдарованість, творчість, креативність, обдарована особистість, становлення обдарованої особистості, трансформаційні зміни соиіуму.

Постановка проблеми. Перетворення, що відбуваються в економіці, політиці, суспільному житті, не можуть не зачіпати систему освіти, в тому числі й вищу. У ситуації, що склалася на тлі посилення негативних тенденцій у молодіжному середовищі предметом діяльності вузу має стати не тільки власне професійна підготовка майбутніх фахівців, а й процес активного включення молодих людей в життя суспільства, освоєння норм життєдіяльності та поведінкових моделей, прийнятих на даному етапі розвитку людської спільноти $[2 ; 5 ; 6]$.

У документах з реформи освіти першорядне значення надається відповідальності системи освіти за духовний та фізичний розвиток сучасного покоління в цілому і кожної особистості окремо, виділяється необхідність розробки ефективних засобів і форм психологічної підтримки процесу самосвідомості і самовизначення особистості. У вузівському середовищі створюються умови не тільки для розвитку професійної культури фахівців, але й для гармонізації інтелектуальної та емоційної сфер особистості, соціалізації, формування моральних орієнтацій та образів-ідеалів особистості в контексті соціальної психології та сучасної суспільної свідомості [1; 3; 4].

Проблема розвитку особистості в освітньому процесі $є$ актуальною ще й $з$ погляду на те, що рівень соціально-психологічної компетентності майбутнього фахівця $є$ одним 3 визначальних чинників здійснення його поведінки у професійній діяльності, можливості творчої реалізації.

Аналіз останніх досліджень і публікацій. В умовах, що склалися, проблема розвитку обдарованої особистості набуває особливої актуальності і стає найважливішим напрямком сучасних емпіричних пошуків і науково-теоретичних досліджень. Ї̈̈ активно розробляють провідні вчені (Ф. Баррон, Дж. Гілфорд, В. Гордон, Г. Лозанов, К. Роджерс, К. Тейлор, Р. Торренс, К. Хаусман, В. Франкл). Процес становлення обдарованої особистості розглядається як міждисциплінарна проблема і вивчається в різних аспектах: уточнюється співвідношення інтелектуальних здібностей, творчих якостей і мислення індивіда (В. Андрєєв, Д. Богоявленська, В. Заїка, І. Кон, Т. Кудрявцев, Я. Пономарьов та ін.), виявляються істотні ознаки креативності як однієї з інтегральних соціально значущих якостей особистості (Р. Мей, Д. Богоявленська), досліджуються творчі здібності та творче 
мислення (О. Кочетов, Ю. Кулюткин, А. Лук і ін.), розглядаються закономірності розвитку творчого потенціалу особистості (М. Бриль, Т. Кудрявцев, І. Семенов та ін.).

Попри всю важливість виконаних досліджень залишаються недостатньо розробленими методологічні та організаційно-методичні аспекти розвитку обдарованої особистості в умовах освітнього середовища вузу. Важливість проведеного дослідження обгрунтовується також й тим, що період навчання у вузі є сензитивним для особистісного розвитку. У процесі навчання у молодих людей формуються певні життєві позиції, які втілюють ставлення до людей, до професійної діяльності, які у подальшому і визначають ступінь компетентності особистості і професіонала. Разом із тим, формування особистості відбувається у взаємодії, в яку людина вступає в навколишньому світі. У даному випадку таким середовищем взаємодії є вуз з усіма учасниками освітнього процесу. Наявність умов для розвитку обдарованої особистості наповнює майбутнє молодої людини сенсом, структурує його і робить суб' єктом свого становлення.

У зв'язку з вищевикладеним виникає необхідність розв'язання суперечності між потребою психологічної теорії і практики у підвищенні рівня розвитку творчої особистості та недостатньою розробленістю ії методологічних і організаційно-методичних основ.

Мета статті - розкрити соціально-психологічний процес становлення обдарованої особистості в умовах трансформаційних змін соціуму.

Виклад основного матеріалу і результатів дослідження. Методологічною основою дослідження послужили наступні наукові ідеї: концепції творчості в філософському (М. Бахтін, М. Бердяєв, В. Біблер, Р. Штейнер та ін.), психологічному (К. Абульханова-Славська, А. Брушлинський, Л. Виготський, О. Леонтьєв, Я. Пономарьов та ін.); теорії креативності (Д. Богоявленська, С. Голубєва, М. Дружинін та ін.); концепція вроджених обдарувань Х. Дуарте; концепції цілісного підходу до процесу становлення особистості (С. Григор'єв, В. Загвязинський, В. Краєвський, В. Полонський); концепції розвитку суб' єктності (К. Абульханова-Славська, А. Мудрик, А. Маслоу, А. Петровський, К. Роджерс, Ж.-Ж. Руссо, В. Франкл, С. Френе, Р. Штейнер та ін.); концептуальні ідеї соціальної підтримки і психологія ненасильства (О. Газман, Б. Лихачов, В. Маралів, В. Ситаров та ін.); постулати гуманістичної психології (К. Роджерс, А. Маслоу, Р. Мей, В. Франкл) і психології, що реалізуються в особистісно-орієнтованому підході до організації освітнього процесу (Л. Виготський, Л. Вяткин, Г. Железовська, І. Зимня, І. Колесникова, О. Леонтьєв, А. Мудрик, В. Сєріков, І. Якиманська та ін.).

Завдання дослідження: провести міждисциплінарне дослідження взаємопов'язаних понять “розвиток обдарованої особистості”, “обдарованість”, “творчість”, “творчий розвиток”, “творча діяльність” в контексті освітнього середовища закладу вищої освіти; проаналізувати науково-теоретичні основи організації освітнього середовища вузу; спроектувати i експериментально апробувати модель освітнього середовища вузу, спрямовану на розвиток творчої особистості майбутнього фахівця.

Методи дослідження, що застосовувалися для вирішення поставлених завдань: теоретичні - теоретико-методологічний міждисциплінарний аналіз наукової літератури, теоретичне моделювання, методи математичної статистики та обробки даних; емпіричні спостереження, аналіз продуктів діяльності, опитування, анкетування, експеримент, бесіда.

Дослідження здійснювалося в три етапи.

На першому етапі здійснювався аналіз літератури з проблеми дослідження, вивчалися особливості розвитку обдарованої особистості в контексті іiі професійної підготовки, розроблялася модель освітнього середовища вузу, спрямована розвиток обдарованої особистості.

На другому етапі розроблявся механізм реалізації моделі освітнього середовища вузу щодо поетапного підвищення рівня прояву творчого розвитку, здійснювалося діагностичне визначення ефективності розробленої моделі, проводилася апробація результатів дослідження у практиці роботи закладів вищої освіти. 
На третьому етапі відбувалося узагальнення і систематизація результатів дослідження, уточнення теоретичних висновків, здійснення коригування механізму реалізації моделі освітнього середовища вузу, спрямованого на розвиток обдарованої особистості; проводилося впровадження результатів роботи в практику освітніх установ.

Теоретико-методологічне обгрунтування проблеми розвитку обдарованої особистості за допомогою занурення їі в освітнє середовище є особливим чином організований соціокультурний і професійно-освітній простір, що створює сукупність якісно різнорідних освітніх умов і надає максимум можливих індивідуально-творчих траєкторій для саморозвитку всіх включених у неї суб'єктів.

Модель освітнього середовища вузу, спрямована на розвиток обдарованої особистості, включала в себе суб'єктне поле (суб'єкти навчально-виховного процесу); змістовне поле (основні напрямки діяльності, представлені в постійних і варіативних програмах і підпрограмах); організаційне поле (включення в творчу діяльність відповідно до змісту програм і підпрограм); інтегроване з ним поле взаємодії з соціумом. Механізм реалізації розробленої соціально-психологічної моделі полягав у детальному описі узгодженого функціонування всіх компонентів освітнього середовища вузу, органічно включений в освітній процес вузу і спрямований на підвищення рівня прояву творчого розвитку особистості.

При здійсненні дослідно-експериментальної роботи ми орієнтувалися на ряд положень, дотримання яких $є$ обов'язковою соціально-психологічною умовою проведення формувального експерименту і визначає його ефективність: творчий розвиток особистості можливий тільки в рамках соціально-психологічної системи, оптимально включеної в розвиваюче середовище; ефективність розвитку обдарованої особистості досягається завдяки функціонуванню керованої системи, організованої за принципом “суб'єктсуб'єктної” взаємодії; оптимальність процесу розвитку обдарованої особистості значно посилюється за рахунок організації управління в усіх ланках освітнього середовища, координації діяльності суб'єктів.

Дані, отримані на кожному етапі дослідно-експериментальної роботи, відображають певну тенденцію до підвищення рівня прояву творчого розвитку особистості, якщо вони входять в освітнє середовище вузу, що підтверджує ефективність розробленої моделі. Навчання в сучасному вузі розглядалося в парадигмі розвиваючої освіти, де поняття освіти $\epsilon$ фундаментальною категорією, яка охоплює процеси соціалізації і виховання, навчання, формування і дорослішання особистості; саме тих процесів, які виявляються загальною формою становлення і розвитку сутнісних сил і творчих здібностей. Рішення загальних питань про умови розвитку особистості, про становлення іiі внутрішнього світу і їi суб'єктності прямо пов'язане з питанням про форми соціальних об'єднань, принципи їх організації, динаміку їх розвитку. У даному випадку йдеться про проектування умов, що сприяють цим процесам, і про виявлення та блокування тих умов, які їм перешкоджають.

Для забезпечення не поверхового, а сутнісного процесу творчості кожного суб' єкта освітній процес потрібно організувати як спеціальну систему заходів і умов, що дозволяє максимально нейтралізувати негативне ставлення освітньої системи до процесу становлення обдарованої особистості. Умовою реалізації механізму такого перетворення Л. Виготський і його послідовники вважали проектування освітнього простору як сукупності якісно різнорідних умов розвитку особистості.

Виходячи $з$ цього, проектування освітнього простору дозволяло охопити його цілісність як безліч особливих підпросторів і можливостей, представити його як спектр освітніх індивідуальних траєкторій. Внаслідок цього соціальна ситуація розвитку реалізується у розвиваючому середовищі як сукупності просторів, відкритих для дії особистості, для становлення особливої субкультури. В результаті освітнє середовище стає засобом розвитку творчих сил кожного включеного в неї індивіда, забезпечує можливість багатовимірного руху особистості в освітньому просторі і створює оптимальні умови для іiі адекватної творчої самореалізації. 
Проведений різнобічний аналіз поняття “середовище” дозволив нам визначити освітнє середовище як особливим чином організований соціокультурний і професійноосвітній простір, що створює сукупність якісно різнорідних освітніх умов і надає максимум можливих індивідуально-творчих траєкторій для саморозвитку всіх включених в неї суб'єктів.

В ході обгрунтування моделі освітнього середовища вузу, спрямованої на розвиток обдарованої особистості, були вирішені такі завдання: виділені аксіологічний і системний підходи до проектування освітнього середовища вузу, спрямованої на розвиток обдарованої особистості; розкрито основні принципи, що лежать в основі проектованого освітнього середовища: гуманізм, духовність, конкурентоспроможність, толерантність, індивідуалізація і варіативність; визначені основні компоненти моделі освітнього середовища вузу, спрямованої на розвиток обдарованої особистості. У моделі освітнього середовища вузу, спрямованої на розвиток обдарованої особистості були введені такі складові: суб'єктна поле, змістовне поле, організаційне поле, інтегровані з ними поле взаємодії з соціумом. Розвиток обдарованої особистості в умовах освітнього середовища здійснюється в результаті їх постійної творчої взаємодії, заснованої на різноманітному діяльнісному спілкуванні, в ході якого відбувається їх взаємне збагачення. Виділено такі напрямки: організаційний, навчально- виховний, суспільно-політичний, науководослідний, культурно-масовий і спортивний. Зазначені напрями знаходять відображення в постійних i варіативних програмах i підпрограма, спрямованих на реалізацію індивідуальних освітніх траєкторій, що сприяють творчому розвитку особистості. Навички самоврядування, творчої організації діяльності прищеплюються з перших днів навчання.

При здійсненні дослідно-експериментальної роботи ми орієнтувалися на ряд положень, дотримання яких є обов'язковою соціально-психологічною умовою проведення формувального експерименту і визначає його ефективність: творчий розвиток особистості можливо тільки в рамках системи, оптимально включеної в розвиваюче середовище; ефективність розвитку обдарованої особистості досягається завдяки функціонуванню керованої системи, реально, а не формально організованою за принципом “суб' єктсуб'єктної’ взаємодії; оптимальність процесу розвитку обдарованої особистості значно посилюється за рахунок організації управління в усіх ланках освітнього середовища, координації діяльності суб'єктів.

Виходячи 3 цього був розроблений механізм реалізації моделі освітнього середовища вузу: розкритио особливості основних складових освітнього середовища; визначено діагностичний інструментарій щодо визначення ефективності реалізації розробленої моделі освітнього середовища, що сприяє розвитку обдарованої особистості; розроблена система контрольно-оцінних методик, що дозволяють 3 високим ступенем достовірності судити про зміну рівня творчого розвитку особистості; скоординовані дії всіх суб'єктів освітнього процесу, які активно взаємодіють в умовах розвиваючого освітнього середовища. Організація освітнього середовища вузу, що сприяє розвитку обдарованої особистості, має здійснюватися поетапно, у певній логічній послідовності. У зв'язку з цим велике значення має розробка змісту змінюваних етапів освітнього процесу.

На підставі проведеного теоретико-методологічного аналізу виокремлено такі етапи формувального експерименту: адаптаційно-орієнтовний; творчо-активізуючий. При цьому кожен етап націлювався на формування певного рівня прояви творчого розвитку особистості, включених в освітнє середовище вузу. Виокремлено такі рівні прояву творчого розвитку особистості: низький рівень (не вірить у власні можливості, не бажає брати участь в різноманітних видах навчальної та позанавчальної творчої діяльності, інертний до участі в роботі творчих об'єднань); середній рівень (сумнівається у своїх можливостях, потребує додаткових стимулів при ініціюванні творчої активності, не наважується брати творчу ініціативу на себе); високий рівень (бере активну участь в різноманітних видах навчальної та позанавчальної творчої діяльності; є ініціатором, здатний на створення широкого спектра самостійних задумів, знаходить нестандартні шляхи і втілює їх у самостійні проекти). 
При вивченні ефективності реалізації моделі освітнього середовища ми передбачили можливість як якісного, так і кількісного аналізу отриманих даних. Дані, одержувані на кожному етапі дослідно-експериментальної роботи, відображають певну тенденцію до підвищення рівня прояву творчого розвитку особистості, якщо вони входять в освітнє середовище вузу, що підтверджує ефективність розробленої моделі.

Висновки. Запропоновано комплексний підхід до дослідження розвитку обдарованої особистості в умовах освітнього середовища вузу; визначені наукові передумови та практичні обгрунтування розробки соціально-психологічної моделі освітнього середовища вузу, спрямованої на розвиток обдарованої особистості, що включає в себе суб' єктне поле, змістовне поле, організаційне поле, інтегроване 3 ними поле взаємодії 3 соціумом. Виокремлено рівні прояву творчого розвитку особистості: низький рівень (не вірить у власні можливості, не бажає брати участь в різноманітних видах навчальної та позанавчальної творчої діяльності, інертний до участі в роботі творчих об'єднань); середній рівень (сумнівається у своїх можливостях, потребує додаткових стимулів при ініціюванні творчої активності, не наважується брати творчу ініціативу на себе); високий рівень (бере активну участь в різноманітних видах навчальної та позанавчальної творчої діяльності; $\epsilon$ ініціатором, здатний на створення широкого спектра самостійних задумів, знаходить нестандартні шляхи і втілює їх у самостійні проекти). Розроблено механізм реалізації моделі освітнього середовища вузу щодо поетапного підвищення рівня прояву творчого розвитку особистості. Постановка і вирішення проблеми пошуку можливостей освітнього середовища вузу для розвитку обдарованої особистості сприяє реалізації ідей особистісно орієнтованої психології; сконструйована модель освітнього середовища вузу, спрямована на розвиток обдарованої особистості, i адекватний механізм іiі реалізації в освітньому процесі вузу відповідає положенням нової парадигми освіти, вносить певний внесок у теорію розвитку особистості.

Подальші дослідження можуть стосуватися конкретизованої розробки окремих компонентів розглянутої моделі освітнього середовища вузу, засобів розвитку творчої особистості студента, дослідження приватних організаційно-практичних питань.

1. Балл Г. О. Про визначальні характеристики здібностей і принципи їх врахування у навчально-виховній роботі. Психологія. Київ : Дніпро, 1992. Вип. 32.

2. Богоявленская Д. Б. Пути к творчеству. Москва : Знание, 1981. 96 с.

3. Волобуєва Т. Б. Розвиток творчої компетентності школярів. Управління школою. Харків, 2005.110 с.

4. Кремень В. Освіта в Україні: стан і перспективи розвитку. Неперевна професійна освіта. Теорія $i$ практика. Київ, 2001. Вип. 4.

5. Подмазин С. И. Личностно ориентированное образование социально-философское исследование. Запорожье : Просвіта, 2000. 84 с.

6. Савчин М. В. Духовний потенціал людини. Івано-Франківськ : Плай, 2001. 204 с. 